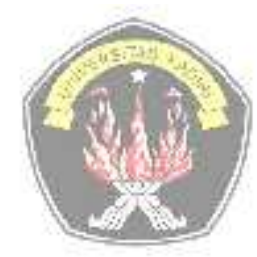

Tersedia online di

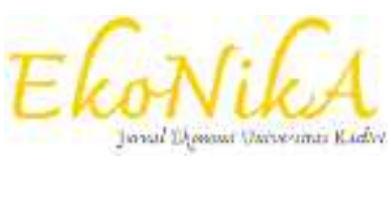

\title{
Pengaruh Produk, Harga Dan Lokasi kepuasan Konsumen Serta Niat Pembelian Ulang Pada Produk Gadai Emas Ib Barokah Di Bank Jatim Cabang Syariah Surabaya
}

\author{
Arys Firmansyah ${ }^{1}$ \\ 1, Universitas Airlangga Surabaya \\ email: ${ }^{1}$ arys.firmansyah@gmail.com
}

\section{Artikel History:}

Artikel masuk : 08-08-2020

Artikel revisi : 07-09-2020

Artikel diterima : 20-09-2020

Keywords:

\begin{abstract}
ABSTRAK
Lingkungan perbankan terus menerus mengalami perubahan dengan semakin bermacam-macam model bisnis yang harus dijalankan sehingga dapat berpengaruh kepada perusahaan baik secara langsung maupun tidak langsung. PT. Bank Pembangunan Daerah Jawa Timur, Tbk adalah salah satu perbankan BUMD terkemuka di Indonesia. Salah satu adanya perubahan yang dilakukan oleh Bank Pembangunan Daerah Jawa Timur, Tbk adalah membuat Unit Usaha Syariah atau yang lebih dikenal dengan nama Bank Jatim Syariah untuk melayani pasar syariah di Indonesia. Sampai dengan tahun 2019, Bank Jatim Syariah telah memiliki 8 kantor cabang yang terletak di Jawa Timur. . Bank Jatim Syariah memiliki berbagai macam produk yang ditawarkan salah satunya adalah Gadai Emas IB Barokah. Produk Gadai Emas IB Barokah mendapat sambutan hangat oleh masyarakat yang membutuhkan penyediaan dana dengan agunan berupa emas perhiasan ataupun emas batangan. Proses pemasaran yang telah dilakukan oleh Bank Jatim Syariah terhadap produk Gadai Emas IB Barokah masih minim dalam evaluasi dari berbagai faktor. Salah satu analisis yang dapat digunakan untuk mengevaluasi keberhasilan dari sisi produk, harga dan lokasi dari Gadai Emas IB. Dalam proses evaluasi terhadap sisi produk, harga dan lokasi terhadap Gadai Emas IB Barokah, Bank Jatim Syariah diharapkan dapat diketahui kepuasan konsumen terhadap produk Gadai Emas IB Barokah serta menimbulkan adanya niat pembelian ulang oleh para konsumen secara terus menerus.
\end{abstract}

\section{ABSTRACT}

The banking environment continues to experience changes with the increasingly diverse business models that must be run so that it can affect companies both directly and indirectly. PT. The Regional Development Bank of East Java, Tbk is one of the leading BUMD banks in Indonesia. One of the changes made by the East Java Regional Development Bank, Tbk is to create a Sharia Business Unit or better known as the Bank Jatim Syariah to serve the sharia market in Indonesia. Until 2019, Bank Jatim Syariah has 8 branch offices located in East Java. Bank Jatim Syariah has a variety of products offered, one of which is IB Barokah Gold Pawn. IB Barokah Gold Pawn Products are warmly received by the public who need to provide funds with collateral in the form of gold 
jewelery or gold bars. The marketing process that has been carried out by Bank Jatim Syariah on the IB Barokah Gold Pawn product is still minimal in the evaluation of various factors. One analysis that can be used to evaluate the success of the product, price and location of IB Gold Pawn. In the process of evaluating the product side, price and location of the IB Barokah Gold Pawn, Bank Jatim Syariah is expected to be able to know the customer satisfaction of the IB Barokah Gold Pawn product as well as giving rise to the intention to repurchase by consumers continuously.

\section{PENDAHULUAN}

Berdasarkan Undang-Undang nomor 10 Tahun 1998 tanggal 10 November 1998 tentang perbankan (pasal 1 ayat 2) Bank adalah sebuah badan usaha yang menghimpun dana dari masyarakat dalam bentuk simpanan dan menyalurkannya kepada masyarakat dalam bentuk kredit dan atau bentuk-bentuk lain dengan tujuan untuk meningkatkan taraf hidup orang banyak. Selain perbankan konvensional juga terdapat perbankan syariah yang ikut berkompetisi dalam dunia perbankan di Indonesia. Berdasarkan Undang - Undang No. 21 Tahun 2008 bank syariah adalah segala sesuatu yang menyangkut tentang Bank Syariah dan Unit Usaha Syariah, mencakup kelembagaan, kegiatan usaha, serta cara dan proses dalam melaksanakan kegiatan usahanya. Bank Syariah adalah bank yang menjalankan kegiatan usahanya berdasarkan prinsip syariah dan menurut jenisnya terdiri atas Bank Umum Syariah dan Unit Usaha Syariah.

Sejarah berdirinya perbankan syariah diawali dengan sejak tahun 1983. Pada tahun tersebut, BI memberikan keleluasaan kepada bank-bank untuk menetapkan suku bunga. Pemerintah berharap dengan kebijakan deregulasi perbankan maka akan tercipta kondisi dunia perbankan yang lebih efisien dan kuat dalam menopang perekonomian. Pada tahun 1983 tersebut pemerintah Indonesia pernah berencana menerapkan "sistem bagi hasil" dalam perkreditan yang merupakan konsep dari perbankan syariah. Bank syariah pertama di Indonesia yaitu PT Bank Muamalat Indonesia (BMI), yang sesuai akte pendiriannya, berdiri pada tanggal 1 Nopember 1991. Sejak tanggal 1 Mei 1992, BMI resmi beroperasi dengan modal awal sebesar Rp 106.126.382.000,- (http://www.ojk.go.id Tahun 2018).

Perkembangan Aset, Dana Pihak Ketiga (DPK) dan Pembiayaan Yang Diberikan (PYD) mengalami peningkatan pada periode tahun 2012-2017 (Gambar 1.1) dan pada akhir tahun 2013, fungsi pengaturan dan pengawasan perbankan berpindah dari Bank Indonesia ke Otoritas Jasa Keuangan (OJK). Dengan demikian pengawasan dan pengaturan perbankan syariah juga 
beralih ke OJK. OJK selaku otoritas sektor jasa keuangan terus menyempurnakan visi dan strategi kebijakan pengembangan sektor keuangan syariah yang telah tertuang dalam Roadmap Perbankan Syariah Indonesia 2015-2019 yang diluncurkan pada Pasar Rakyat Syariah 2014.

Dengan semakin berkembangnya perbankan syariah membuat masyarakat menjadi memiliki pilihan lain dalam memilih perbankan yang akan digunakan. Dengan semakin berkembangnya perbankan syariah dapat mengancam eksistensi bank konvensional dan BPD (Bank Pembangunan Daerah) sebagai lembaga keuangan favorit pilihan masyarakat. Pada awal tahun 2000 an banyak perbankan konvensional yang mendirikan perbankan syariah sebagai salah satu unit bisnisnya. Salah satu perbankan syariah yang ada di Indonesia adalah Unit Usaha Syariah (UUS) BPD Jawa Timur atau yang lebih dikenal dengan nama Bank Jatim Cabang Syariah Surabaya.

Dalam menjalankan bisnis pembiayaan, Bank Jatim Cabang Syariah Surabaya meluncurkan beberapa produk salah satunya adalah program pembiayaan Gadai Emas. Pembiayaan Gadai Emas di Bank Jatim Cabang Syariah Surabaya bernama Gadai Emas IB Barokah dan merupakan salah satu produk yang masuk dalam kategori pembiayaan produktif dan konsumtif. Perkembangan produk pembiayaan Gadai Emas di Bank Jatim Cabang Syariah Surabaya mengalami penurunan pada tahun 2016-2017 kemudian mengalami peningkatan kembali pada tahun 2017 - 2018. Berikut ini adalah data jumlah konsumen Gadai Emas IB Barokah di Bank Jatim Syariah Cabang Surabaya.

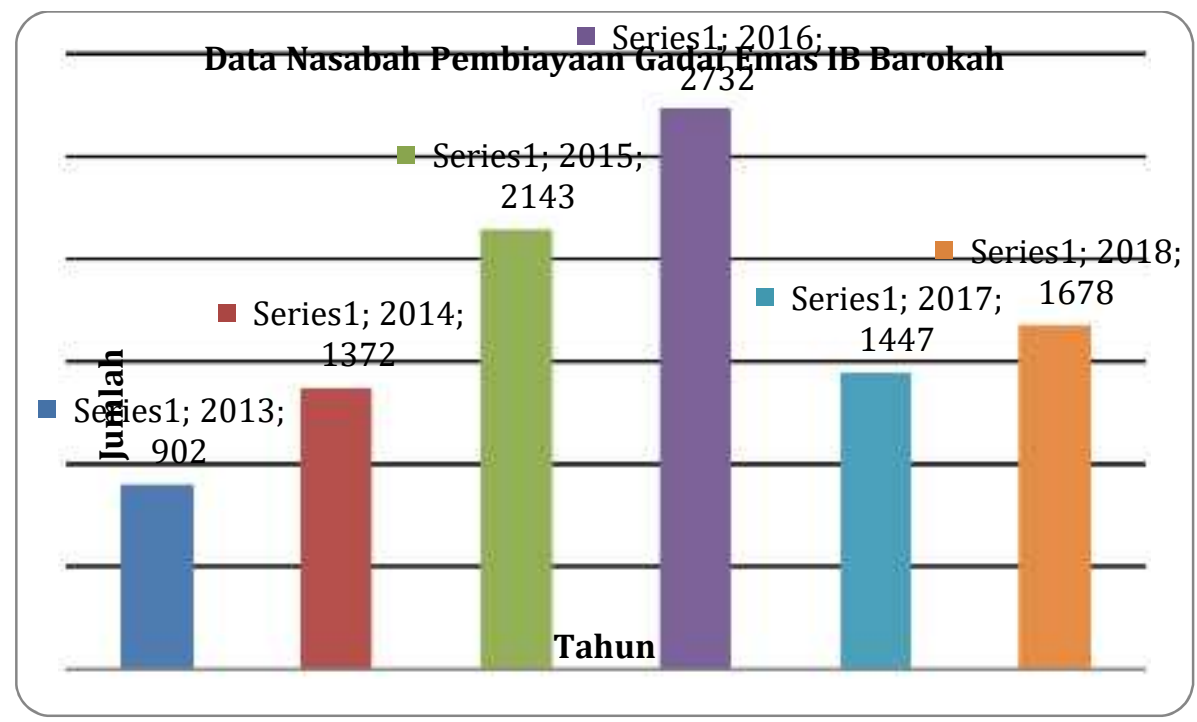

Gambar 1.Data Nasabah Pembiayaan Gadai Emas IB Barokah

Sumber : Laporan Keuangan Bank Jatim 2014-2018 
Berdasarkan Gambar 1, pada tahun 2013 - 2016 mengalami peningkatan rata-rata sebesar 45,26\%. Pada tahun 2016 - 2017 terjadi penurunan sebesar 47,04\% dan kembali meningkat pada tahun 2017 - 2018 sebesar 15,96\%. Menurut Bapak Ferico selaku penyelia operasional pembiayaan di Bank Jatim Cabang Syariah Surabaya mengungkapkan bahwa pada tahun 2018 terdapat peningkatan dalam pertumbuhan nasabah Gadai Emas namun peningkatan tersebut tidak sebanding dengan penurunan yang terjadi pada 2016 - 2017. Secara strategi pemasaran yang ditetapkan oleh Bank Jatim Cabang Syariah Surabaya dirasa kurang agresif dalam merebut pasar Gadai Emas di Surabaya dan sekitarnya.

Berdasarkan hasil informasi yang didapat melalui wawancara dengan pihak manajemen Bank Jatim Syariah Cabang Surabaya dan beberapa konsumen Gadai Emas IB Barokah dapat disimpulkan bahwa faktor -faktor yang mempengaruhi konsumen gadai emas masih setia menggunakan produk Gadai Emas IB Barokah adalah kepuasan atas faktor produk, kepuasan atas faktor harga dan kepuasan atas faktor tempat. Ketiga faktor tersebut diharapkan dapat memberikan informasi mengenai kepuasan konsumen gadai emas dan niat pembelian ulang terhadap produk Gadai Emas IB Barokah di Bank Jatim Cabang Syariah Surabaya.

Menurut Kotler dan Keller (2016), niat pembelian ulang merupakan perilaku yang muncul sebagai respon terhadap obyek ketika seseorang konsumen memperoleh respon positif atas tindakan masa lalu. Menurut Zeithaml et al. (2006), niat pembelian ulang dapat diukur melalui indikator Do Repeat Purchase yaitu konsumen berniat melakukan pembelian ulang dari produk dengan merek tertentu dengan tujuan digunakan sendiri atau untuk orang lain. Niat pembelian ulang yang dimaksud dalam penelitian ini adalah penialaian responden terhadap suatu sikap dan hasrat yang secara kuat mendorong nasabah Gadai Emas IB Barokah untuk terus menggunakan produk Gadai Emas IB Barokah di Bank Jatim Cabang Syariah Surabaya.

Berdasarkan peneltian yang dilakukan oleh Agyapong(2016)menyatakan bahwa ketika pelanggan sangat puas dengan layanan yang diberikan, biaya yang dibayarkan menjadi tidak relevan bagi pelanggan untuk beralih penyedia layanankarena kepuasan pelanggan mempengaruhi pembelian kembali layanan. Kepuasan konsumen menurut Kotler dan Keller (2016)adalah perasaan puas atau kecewa seseorang yang dihasilkan dari perbandingan performa produk atau hasil dengan ekspektasi. Jika performanya kurang dari ekspektasi maka konsumenakan kecewa dan jika sesuai dengan ekspektasi konsumen akan merasa puas diartikan sebagai upaya pemenuhan sesuatu atau membuat sesuatu memadai. Kepuasan konsumen dalam penelitian ini meliputi kepuasan nasabah tehadap pelayanan yang diberikan oleh Bank Jatim Cabang Syariah Surabaya, memiliki niat berkunjung kembali ke Bank Jatim Cabang Syariah 
Surabaya dan kesediaan untuk merekomendasi produk Gadai Emas IB Barokah di Bank Jatim Cabang Syariah Surabaya.

Berdasarkan penelitian yang dilakukan oleh Razak et al., (2016) menyatakan bahwa bahwa peningkatan kualitas produk yang kompetitif dapat meningkatkan kepuasan pelanggan. Pengertian produk menurut Kotler dan Keller (2016) adalah segala sesuatu yang dapat ditawarkan ke pasar untuk memuaskan keinginan atau kebutuhan, termasuk barang fisik, layanan, pengalaman, acara, orang, tempat, properti, organisasi, informasi dan ide. Pengertian produk menurut Tjiptono (2015) adalah pemahaman subyektif produsen atas 'sesuatu' yang bisa ditawarkan sebagai usaha untuk mencapai tujuan organisasi melalui pemenuhan kebutuhan dan keinginan konsumen, sesuai dengan kompetensi dan kapasitas organisasi serta daya beli pasar. Berdasarkan pengertian produk dapat disimpulkan bahwa produk merupakan segala sesuatu baik yang berwujud ataupun tidak berwujud yang ditawarkan kepada pasar sebagai pemenuhan kebutuhan atau pemenuhan kepuasan keinginan konsumen. Dalam penelitian ini yang dimaksud dengan produk adalah pembiayaan gadai emas yang ditawarkan oleh Bank Jatim Cabang Syariah Surabaya. Pembiayaan gadai emas tersebut dapat digunakan untuk memenuhi kebutuhan konsumtif dan produktif.

Berdasarkan penelitian yang dilakukan oleh Ehsani dan Ehsani(2015) menyatakan bahwa harga bisa digunakan sebagai sumber daya untuk meningkatkan laba dan pelanggan kepuasan. Ketika harga wajar, tetapi kualitasnya buruk, itu akan menghalangi pelanggan untuk membeli suatu produk. Demikian juga, jika harga sangat tinggi berdasarkan kualitas yang diberikan, itu juga akan menghalangi pembelian dankepuasan. Pengertian harga menurutKotler dan Armstrong (2016) adalah pengorbanan finansial yang dibebankan untuk sebuah produk atau jasa. Secara lebih luas, harga adalah keseluruhan nilai yang ditukarkan konsumen untuk mendapatkan keuntungan dari kepemilikan terhadap sebuah produk atau jasa. Menurut Alma(2014),harga adalah nilai suatu barang atau jasa yang dinyatakan dengan uang.Harga merupakan satu-satunya dari unsur bauran pemasaran (marketing mix) yang menghasilkan pendapatan sementara unsur-unsur lainnya menimbulkan biaya. Berdasarkan pendapat dari para ahli tersebut dapat disimpulkan bahwa sejumlah uang yang dibayar sebagai imbalan atas apa yang telah dinikmati konsumen. Aspek harga dalam penelitian ini adalah bagaimana penerapan margin (suku bunga) yang ditetapkan dalam pembiayaan pembiayaan gadai emas di Bank Jatim Cabang Syariah Surabaya.

Berdasarkan penelitian yang dilakukan oleh Kana, (2018)menyatakan bahwa lokasi berpengaruh positif dan signifikan terhadap kepuasan pengguna pemuatan dan pembongkaran layanan kontainer di mana indikator yang ada pada aspek lokasi adalah akses, visibilitas, lalu 
lintas mempengaruhi kepuasan pengguna layanan pemuatan. Pengertian Lokasi menurut Tjiptono dan Diana(2015) Lokasi mengacu pada berbagai aktivitas pemasaran yang berusaha memperlancar dan mempermudah penyampaian atau penyaluran barang dan jasa dari produsen kepada konsumen. Pengertian tempat menurut Kotler dan Armstrong (2016)adalah berbagai kegiatan perusahaan untuk membuat produk yang dihasilkan/dijual terjangkau dan tersedia bagi pasar sasaran. Pengertian tempat menurut Lupiyoadi dan Hamdani(2014)adalah keputusan yang dibuat perusahaan atau instansi pendidikan berkaitan dengan di mana operasi dan stafnya akan ditempatkan. Berdasarkan pengertian lokasi dari berbagai peneliti dapat disimpulkan bahwa lokasi adalah suatu keputusan perusahaan untuk menentukan tempat usaha, menjalankan kegiatan usaha atau kegiatan operasional, dan mendistribusikan barang atau jasa yang menjadi kegiatan bisnisnya kepada konsumen. Pentingnya lokasi bagi perusahaan atau pengusaha sangat mempengaruhi keputusan sasaran pasar dalam menentukan keputusan pembeliannya. Aspek tempat dalam penelitian ini merupakan lokasi dari Bank Jatim Cabang Syariah Surabaya.

Pada penelitian ini membahas mengenai pengaruh produk, harga dan lokasi terhadap kepuasan konsumen Gadai Emas IB Barokah di Bank Jatim Syariah Surabaya sehingga dapat diketahui faktor -faktor yang menyebabkan para konsumen Gadai Emas IB Barokah tetap setia dengan menggunakan produk Gadai Emas IB Barokah secara berulang ulang. Objek dalam penelitian ini adalah para konsumen Gadai Emas IB Barokah di Bank Jatim Cabang Syariah Surabaya.

\section{TINJAUAN PUSTAKA}

Di dalam ruang lingkup pemasaran terdapat apa yang dinamakan dengan bauran pemasaran (marketing mix). Bauran pemasaran merupakan serangkaian variabel pemasaran yang harus dikuasai dan dipahami oleh perusahaan untuk dapat mencapai tujuan perusahaan. Untuk lebih jelasnya mengenai definisi bauran pemasaran, berikut definisi dari ahli pemasaran yaitu : Bauran pemasaran menurut Kotler dan Keller(2016), bauran pemasaran (marketing mix) adalah perangkat alat pemasaran yang digunakan perusahaan untuk mengejar tujuan pemasarannya. Sedangkan pengertian bauran pemasaran menurut Alma(2014), diartikan sebagai berikut :"Bauran pemasaran merupakan strategi mencampuri kegiatan - kegiatan pemasaran, agar dicari kombinasi maksimal sehingga mendatangkan hasil yang memuaskan. Bauran Pemasaran terdiri atas empat komponen atau disebut 4P yaitu product, price, place, promotion."

\subsection{Produk}

Pengertian produk menurut Kotler dan Keller(2016)adalah segala sesuatu yang dapat ditawarkan ke pasar untuk memuaskan keinginan atau kebutuhan, termasuk barang fisik, layanan, pengalaman, acara, orang, tempat, properti, organisasi, informasi dan ide. Pengertian produk menurut Tjiptono dan Diana(2015)adalah pemahaman subyektif produsen atas 'sesuatu' yang bisa ditawarkan sebagai usaha untuk mencapai tujuan organisasi melalui pemenuhan kebutuhan dan keinginan konsumen, sesuai dengan kompetensi dan kapasitas organisasi serta daya beli pasar. Berdasarkan pengertian 
produk dapat disimpulkan bahwa produk merupakan segala sesuatu baik yang berwujud ataupun tidak berwujud yang ditawarkan kepada pasar sebagai pemenuhan kebutuhan atau pemenuhan kepuasan keinginan konsumen.

\subsection{Harga}

Pengertian harga menurut Kotler dan Armstrong (2016) adalah pengorbanan finansial yang dibebankan untuk sebuah produk atau jasa. Secara lebih luas, harga adalah keseluruhan nilai yang ditukarkan konsumen untuk mendapatkan keuntungan dari kepemilikan terhadap sebuah produk atau jasa. Menurut Alma(2014),harga adalah nilai suatu barang atau jasa yang dinyatakan dengan uang. Harga merupakan satu-satunya dari unsur bauran pemasaran (marketing mix)yang menghasilkan pendapatan sementara unsur-unsur lainnya menimbulkan biaya. Berdasarkan pendapat dari para ahli tersebut dapat disimpulkan bahwa sejumlah uang yang dibayar sebagai imbalan atas apa yang telah dinikmati konsumen.

\subsection{Lokasi}

Pengertian lokasi menurut Kotler dan Armstrong (2016) adalah suatu tempat dimana perusahaan melakukan aktvitasnya untuk menargetkan konsumennya. Pengertian lokasi menurut Lovelock dan Wright(2005) lokasi adalah keputusan yang dibuat oleh manajemen mengenai dimana dan bagaimana jasa tersebut dapat sampai kepada konsumen. Menurut Zeithaml dan Bitner(2000), lokasi adalah berbagai kegiatan yang dilakukan perusahaan agar produk/jasa dapat diperoleh dan tersedia bagi pasar sasaran. Pengertian lokasi menurut Alma(2014) adalah tempat perusahaan beroperasi atau tempat perusahaan melakukan kegiatan untuk menghasilkan barang dan jasa yang mementingkan segi ekonominya. Pendapat mengenai lokasi dari para ahli tersebut, sampai pada pemahaman penulis bahwa lokasi adalah suatu tempat dimana perusahaan beroperasi dan menghasilkan barang dan jasa serta pemilihan suatu lokasi perusahaan sangat menentukan keberhasilan suatu usaha.

\subsection{Kepuasan Konsumen}

Upaya dalam memenuhi kepuasan konsumen, perusahaan memang dituntut untuk mengetahui pergeseran kebutuhan dan keinginan konsumen yang hampir setiap saat berubah. Pembeli akan bergerak setelah membentuk persepsi terhadap nilai penawaran, kepuasan sesudah pembelian tergantung dari kinerja penawaran dibandingkan dengan harapannya. Kepuasan konsumen didefinisikan oleh Kotler dan Keller(2016) adalah perasaan senang atau kecewa seseorang yang muncul setelah membandingkan kinerja (hasil) produk yang dipikirkan terhadap kinerja yang diharapkan. Kepuasan konsumen menurut Kotler dan Armstrong (2016) merupakan tingkat perasaan seseorang ketika menerima produk atau jasa yang ditawarkan serta membandingkan kinerja atas produk atau jasa yang diterima tersebut dengan harapan konsumen. Kepuasan konsumen satu dengan lainnya akan berbeda sesuai dengan persepsi, keinginan dan kebutuhan konsumen tersebut. Berdasarkan pengertian kepuasan konsumen dari para ahli tersebut dapat disimpulkan bahwa pengertian kepuasan konsumen adalah tingkat perasaan seseorang ketika menerima produk atau jasa yang ditawarkan serta membandingkan kinerja atas produk atau jasa yang diterima dengan harapan yang dimiliki.

1.5 Niat Pembelian Ulang

Repurchase intention didefinisi sebagai keinginan yang muncul dari dalam diri pelanggan untuk melakukan pembelian kembali suatu produk atau jasa darisuatu perusahaan yang sama berdasarkan hasil evaluasi atas kesesuaian kinerja produk atau jasa dengan harapan pelanggan (Hellier et al., 2003). Niat untuk melakukan pembelian ulang terjadi setelah pelanggan pernah melakukan pembelian sebelumnya, sehingga berniat untuk melakukan pemembelian ulang produk atau jasa yang sama (Palmer dan Keown-McMullan, 2000). Oliver (1999)dalam(Varga et al.,2014) mendefinisikan 
loyalitas mempunyai komitmen yang sangat kuat untuk melakukan repurchase intention atau mengganti kembali produk atau layanan yang sama (Varga et al.,2014). Dari beberapa definisi diatas penulis dapat menyimpulkan bahwa repurchase intention merupakan hasrat atau keinginan yang timbul dalam diri pelanggan yang loyaluntuk membeli produk atau jasa yang disukai dan sebelumnya pernah melakukan pembelian berdasarkan hasil evaluasi atas kesesuaian kinerja produk atau jasa dengan harapan Hipotesis pelanggan.

H1: Produk berpengaruh positif terhadap Kepuasan Konsumen.

H2: Harga berpengaruh negatif terhadap Kepuasan Konsumen.

H3: Lokasi berpengaruh positif terhadap Kepuasan Konsumen.

H4: Kepuasan Konsumen berpengaruh positif terhadap Niat Pembelian Ulang.

\section{METODE PENELITIAN}

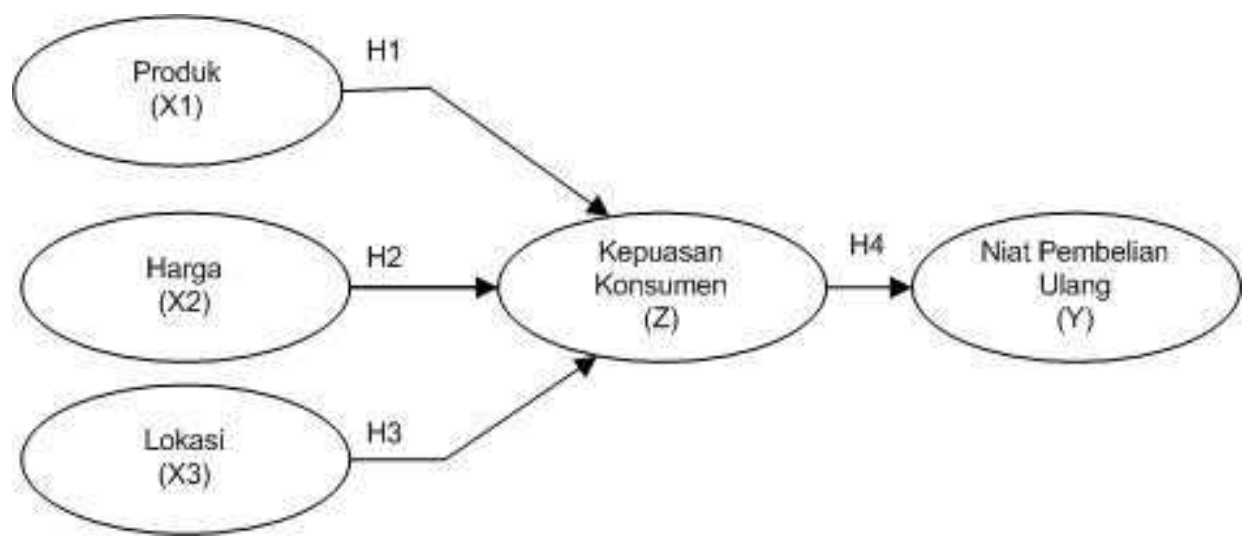

Gambar 2. Model Penelitian

Populasi

Populasi adalah sekelompok entitas yang memiliki karakteristik yang sama (Zikmund et al., 2013). Populasi dalam penelitian ini adalah nasabah Gadai Emas IB Barokah di Bank Jatim Cabang Syariah Surabaya.

Sampel

Pengertian sampel menurut Neuman (2013) adalah sebagian responden dari populasi yang dipilih peneliti dari himpunan besar dan akan menggeneralisasi pada populasi. Pada penelitian ini menggunakan non-probability sampling dengan teknik purposive sampling. Pengertian purposive sampling menurut Neuman (2013) adalah teknik sampling dengan menggunakan persyaratan tertentu agar dapat menjaring sampel yang representatif pada populasi yang tidak dapat diketahui. Alasan menggunakan teknik Purposive Sampling adalah karena tidak semua sampel memiliki kriteria yang sesuai dengan fenomena yang diteliti. Oleh karena itu, penulis memilih teknik Purposive Sampling yang menetapkan pertimbangan-pertimbangan atau kriteriakriteria tertentu yang harus dipenuhi oleh sampel-sampel yang digunakan dalam penelitian ini.

Dalam penelitian ini yang menjadi sampel yaitu perusahaan yang memenuhi kriteria tertentu. Adapun kriteria yang dijadikan sebagai sampel penelitian yaitu:

1. Konsumen Gadai Emas IB Barokah di Bank Jatim Cabang Syariah Surabaya sedang menggunakan produk Gadai IB Barokah. 
2. Konsumen Gadai Emas IB Barokah di Bank Jatim Cabang Syariah Surabaya telah melakukan perpanjangan fasilitas minimal 1 kali.

Definisi Operasional Variabel

Produk (X1)

Definisi Operasional Variabel produk antara lain :

1. Plafond pembiayaan dari Produk Gadai Emas IB Barokah di Bank Jatim Cabang Syariah Surabaya tinggi.

2. Taksiran Gadai Emas IB Barokah di Bank Jatim Cabang Syariah Surabaya tinggi.

3. Produk Gadai Emas IB Barokah di Bank Jatim Syariah Surabaya memiliki jangka waktu pembiayaan panjang.

Harga (X2)

Definisi Operasional Variabel harga antara lain :

1. Biaya administrasi Gadai Emas IB Barokah untuk murah.

2. Biaya administrasi untuk perpanjangan Gadai Emas IB Barokah murah.

3. Marjin Gadai Emas IB Barokah di Bank Jatim Cabang Syariah Surabaya rendah.

Lokasi (X3)

Definisi Operasional Variabel lokasi antara lain :

1. Kantor Bank Jatim Cabang Syariah Surabaya terletak di lokasi yang memudahkan konsumen untuk menjangkaunya.

2. Kantor Bank Jatim Cabang Syariah Surabaya nyaman untuk bertransaksi

3. Kantor Bank Jatim Cabang Syariah Surabaya mudah diakses oleh alat transportasi

Kepuasan Konsumen $(\mathrm{Z})$

Definisi Operasional Variabel Kepuasan Konsumen antara lain :

1. Pelayanan Bank Jatim Cabang Syariah Surabaya yang diberikan sesuai dengan yang diharapkan.

2. Penawaran Gadai Emas IB Barokah sesuai dengan yang diharapkan.

3. Secara keseluruhan terdapat perasaan senang dengan Gadai Emas IB Barokah di Bank Jaim Cabang Syariah Surabaya.

Niat Pembelian Ulang (Y)

Definisi Operasional Variabel Niat Pembelian Ulang antara lain :

1. Nasabah menggunakan produk Gadai Emas IB Barokah secara terus menerus.

2. Setiap ada keperluan gadai emas, nasabah menggunakan produk Gadai Emas IB Barokah di Bank Jatim Syariah Cabang Surabaya.

Nasabah menggunakan kembali produk Gadai Emas IB Barokah. 


\section{HASIL \& PEMBAHASAN}

3 Hasil dan Pembahasan

Tabel 1. Profil Responden

\begin{tabular}{|c|c|c|c|}
\hline \multicolumn{4}{|c|}{ Jenis Kelamin } \\
\hline No & Jenis Kelamin & Jumlah & Persentase (\%) \\
\hline 1 & Laki - Laki & 48 & $43,6 \%$ \\
\hline 2 & Perempuan & 62 & $56,4 \%$ \\
\hline \multicolumn{4}{|c|}{ Usia } \\
\hline No & Usia & Jumlah & Persentase (\%) \\
\hline 1 & $>17$ - 25 Tahun & 10 & $9,1 \%$ \\
\hline 2 & $>25$ - 35 Tahun & 46 & $41,8 \%$ \\
\hline 3 & > 35 - 45 Tahun & 40 & $36,4 \%$ \\
\hline 4 & $>45$ - 55 Tahun & 14 & $12,7 \%$ \\
\hline 5 & > 55 Tahun & $\mathbf{0}$ & $0,0 \%$ \\
\hline \multicolumn{4}{|c|}{ Lama Bekerja } \\
\hline 1 & $\leq 1$ Tahun & 37 & $33,6 \%$ \\
\hline 2 & 1 - 2 Tahun & 29 & $26,4 \%$ \\
\hline 3 & > 2 - 3 Tahun & 23 & $20,9 \%$ \\
\hline 4 & > 3 Tahun & 21 & $19,2 \%$ \\
\hline
\end{tabular}

Berikut adalah penjelasan tahapan analisis Partial Least Square selengkapnya:

Dalam melakukan pengolahan data yang terdapat dalam penelitian ini, menggunakan metode Partial Least Square (PLS) dengan bantuan software Smart PLS 2. Model struktural Smart PLS 2 dipergunakan untuk mengetahui pengaruh dari variabel produk, harga dan lokasi terhadap kepuasan konsumen serta hubungannya dengan variabel niat pembelian ulang pada nasabah Gadai Emas IB Barokah Bank Jatim Cabang Syariah Surabaya dengan gambar model sebagai berikut:

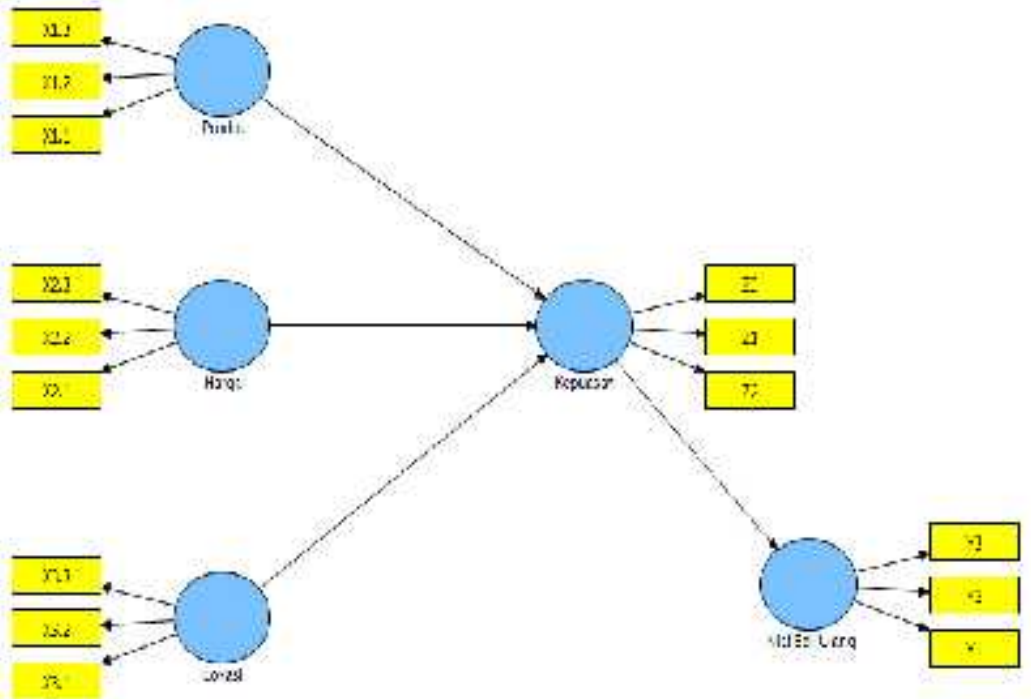

Gambar 4.1 Model Struktual Smart PLS 
Dalam melakukan analisis dengan Partial Least Square (PLS) terdiri atas dua evaluasi yang meliputi evaluasi outer model dan inner model. Berikut ini merupakan beberapa uraian mengenai langkah evaluasinya.

\subsection{Evaluasi Outer Model}

Hasil dari estimasi Algorithm dengan Smart PLS 2 dengan sampel 110 nasabah adalah sebagai berikut:

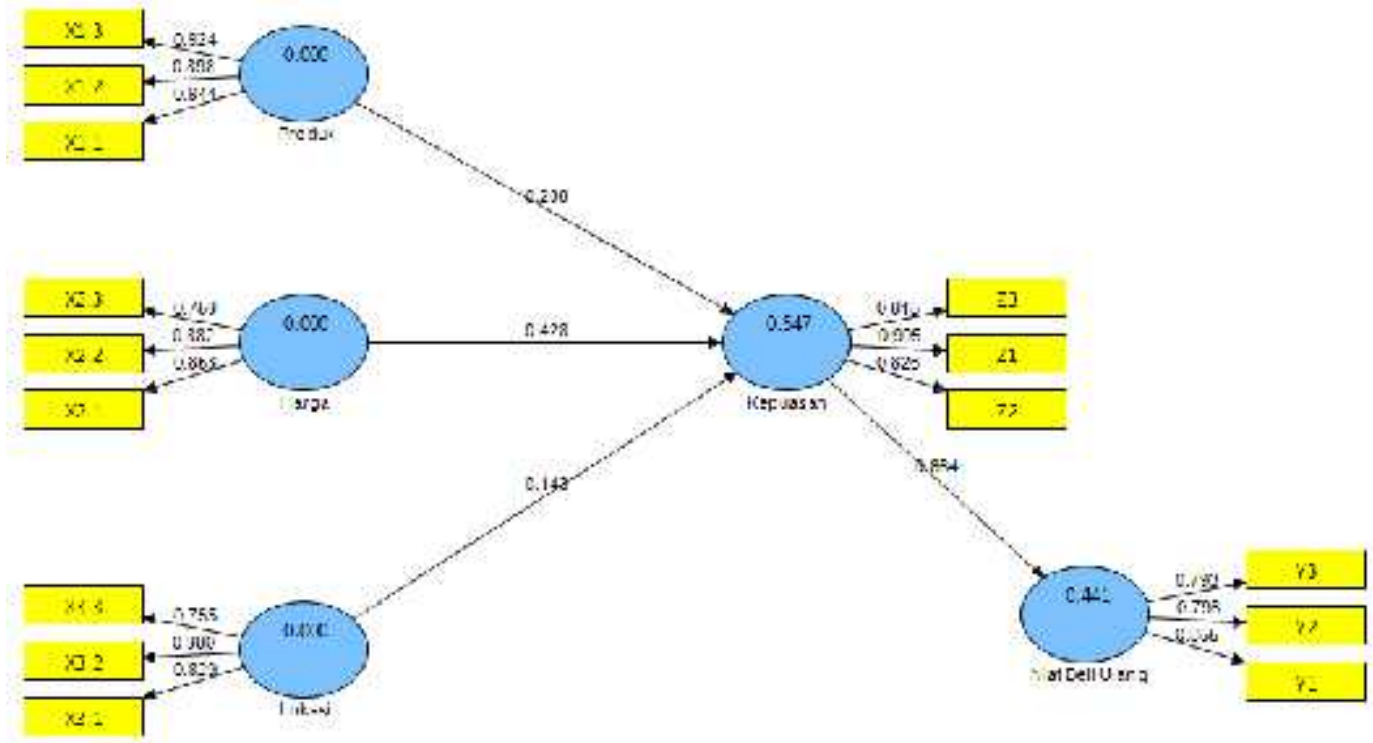

Gambar 4.2 Hasil Estimasi Algorithm Smart PLS

Dalam mengevaluasi outer model adalah dengan melakukan pengukuran measurement model pada variabel-variabel penelitian. Evaluasi yang dilakukan meliputi pengujian convergent validity, discriminant validity dan composite reliability.

a. Convergen Validity

Tabel 4.10

Nilai Outer Loading \& AVE Model Struktural

\begin{tabular}{|c|c|c|c|}
\hline Variabel & Indikator & $\begin{array}{l}\text { Nilai Outer } \\
\text { Loading }\end{array}$ & $\begin{array}{l}\text { Average Variance } \\
\text { Extracted (AVE) }\end{array}$ \\
\hline \multirow{3}{*}{ Produk } & $\mathrm{X} 1.1$ & 0,944 & \multirow{3}{*}{0,850} \\
\hline & $\mathrm{X} 1.2$ & 0,898 & \\
\hline & $\mathrm{X} 1.3$ & 0,924 & \\
\hline \multirow{3}{*}{ Harga } & $\mathrm{X} 2.1$ & 0,858 & \multirow{3}{*}{0,697} \\
\hline & $\mathrm{X} 2.2$ & 0,882 & \\
\hline & $\mathrm{X} 2.3$ & 0,758 & \\
\hline \multirow{3}{*}{ Lokasi } & $\mathrm{X} 3.1$ & 0,829 & \multirow{3}{*}{0,678} \\
\hline & X3.2 & 0,880 & \\
\hline & X3.3 & 0,755 & \\
\hline \multirow{3}{*}{$\begin{array}{l}\text { Kepuasan } \\
\text { Konsumen }\end{array}$} & $\mathrm{Z1}$ & 0,905 & \multirow{3}{*}{0,722} \\
\hline & $\mathrm{Z} 2$ & 0,826 & \\
\hline & $\mathrm{Z3}$ & 0,815 & \\
\hline \multirow{3}{*}{$\begin{array}{l}\text { Niat Pembelian } \\
\text { Ulang }\end{array}$} & $\mathrm{Y} 1$ & 0,855 & \multirow{3}{*}{0,664} \\
\hline & $\mathrm{Y} 2$ & 0,796 & \\
\hline & Y3 & 0,793 & \\
\hline
\end{tabular}

b. Discriminant Validity 
Setelah dilakukan evaluasi convergent validity, selanjutnya adalah mengevaluasi discriminant validity yang meggunakan evaluasi fornell-larcker dan nilai cross loading sebagai pengukurnya.

Tabel 4.11

Evaluasi Fornell-Larcker

\begin{tabular}{|l|c|c|c|c|c|}
\hline \multicolumn{1}{|c|}{ Variabel } & Produk & Harga & Lokasi & Kepuasan & $\begin{array}{c}\text { Niat Beli } \\
\text { Ulang }\end{array}$ \\
\hline Produk & $\mathbf{0 , 9 2 2}$ & & & & \\
\hline Harga & 0,695 & $\mathbf{0 , 8 3 5}$ & & & \\
\hline Lokasi & 0,490 & 0,526 & $\mathbf{0 , 8 2 3}$ & & \\
\hline Kepuasan Konsumen & 0,630 & 0,686 & 0,509 & $\mathbf{0 , 8 5 0}$ & \\
\hline Niat Pembelian Ulang & 0,664 & 0,603 & 0,550 & 0,664 & $\mathbf{0 , 8 1 5}$ \\
\hline
\end{tabular}

Berdasarkan pada Tabel 4.11 evaluasi Formell-Larcker Hasil Fornel - Larcker diketahui bahwa nilai akar AVE setiap variabel penelitian (bold) yang berada pada baris diagonal memiliki nilai yang lebih besar dibandingkan dengan korelasi antar variabel penelitian (tidak bold). Dengan demikian, dari hasil evaluasi Fornel-Larcker disimpulkan bahwa evaluasi discriminant validity dari analisis PLS sudah dapat terpenuhi. Sementara itu, evaluasi lainnya dengan menggunakan cross loading terlihat bahwa nilai outer loading terbesar dari hasil cross loading pada setiap variabel diperoleh nilai tertinggi pada variabel yang memang diukurnya. Hal tersebut menunjukkan bahwa evaluasi discriminant validity dengan menggunakan kriteria cross loading juga telah menunjukkan discriminant validity yang baik. Hasil dari nilai cross loading ditampilkan pada Tabel 4.12 di bawah ini:

Tabel 4.12

Evaluasi Cross Loading

\begin{tabular}{|c|c|c|c|c|c|}
\hline & Produk & Harga & Lokasi & Kepuasan & Niat Beli Ulang \\
\hline X1.1 & $\mathbf{0 . 9 4 4}$ & 0.640 & 0.458 & 0.615 & 0.604 \\
\hline X1.2 & $\mathbf{0 . 8 9 8}$ & 0.533 & 0.448 & 0.545 & 0.598 \\
\hline X1.3 & $\mathbf{0 . 9 2 4}$ & 0.580 & 0.451 & 0.580 & 0.636 \\
\hline X2.1 & 0.608 & $\mathbf{0 . 8 5 8}$ & 0.467 & 0.618 & 0.533 \\
\hline X2.2 & 0.497 & $\mathbf{0 . 8 8 2}$ & 0.410 & 0.631 & 0.507 \\
\hline X2.3 & 0.485 & $\mathbf{0 . 7 5 8}$ & 0.455 & 0.442 & 0.471 \\
\hline X3.1 & 0.375 & 0.530 & $\mathbf{0 . 8 2 9}$ & 0.440 & 0.465 \\
\hline X3.2 & 0.522 & 0.458 & $\mathbf{0 . 8 8 0}$ & 0.479 & 0.550 \\
\hline X3.3 & 0.276 & 0.274 & $\mathbf{0 . 7 5 5}$ & 0.313 & 0.304 \\
\hline Z1 & 0.566 & 0.642 & 0.474 & $\mathbf{0 . 9 0 5}$ & 0.604 \\
\hline Z2 & 0.481 & 0.545 & 0.316 & $\mathbf{0 . 8 2 6}$ & 0.531 \\
\hline Z3 & 0.554 & 0.556 & 0.496 & $\mathbf{0 . 8 1 5}$ & 0.554 \\
\hline Y1 & 0.565 & 0.530 & 0.585 & 0.603 & $\mathbf{0 . 8 5 5}$ \\
\hline Y2 & 0.469 & 0.414 & 0.443 & 0.472 & $\mathbf{0 . 7 9 6}$ \\
\hline Y3 & 0.581 & 0.520 & 0.303 & 0.536 & $\mathbf{0 . 7 9 3}$ \\
\hline
\end{tabular}


c. Composite Reliability

Evaluasi terakhir pada outer model adalah composite reliability yang menguji nilai reliabilitas pada masing-masing indikator dalam suatu variabel. Suatu variabel dikatakan telah memenuhi composite reliability apabila nilai composite reliability lebih dari 0,7 serta nilai cronbach alpha lebih besar dari $\mathbf{0 , 6 0}$. Berikut ini merupakan nilai composite reliability pada masing-masing variabel.

Tabel 4.13

Nilai Composte Reliability dan Cronbach Alpha

\begin{tabular}{|l|c|c|}
\hline \multicolumn{1}{|c|}{ Variabel } & $\begin{array}{c}\text { Composite } \\
\text { Reliability }\end{array}$ & $\begin{array}{c}\text { Cronbach } \\
\text { Alpha }\end{array}$ \\
\hline Produk & 0,944 & 0,912 \\
\hline Harga & 0,873 & 0,783 \\
\hline Lokasi & 0,863 & 0,765 \\
\hline Kepuasan Konsumen & 0,886 & 0,806 \\
\hline Niat Pembelian Ulang & 0,856 & 0,748 \\
\hline
\end{tabular}

Berdasarkan Tabel 4.13 terlihat bahwa setiap variabel dalam model penelitian memiliki nilai composite reliability yang lebih besar dari 0,7 . Sementara itu, untuk nilai cronbach alpha juga diperoleh nilai yang kesemuanya telah lebih besar dari 0,60. Mengacu pada hasil evaluasi ini, maka dapat disimpulkan bahwa pada masing-masing variabel penelitian telah memenuhi composite reliability.

\subsubsection{Evaluasi Inner Model}

Pada evaluasi ini akan diberikan uraian mengenai hasil $R$-square dan pengujian hipotesis yang didapatkan dari hasil proses bootstrapping Smart PLS 2 dengan hasilnya adalah sebagai berikut:

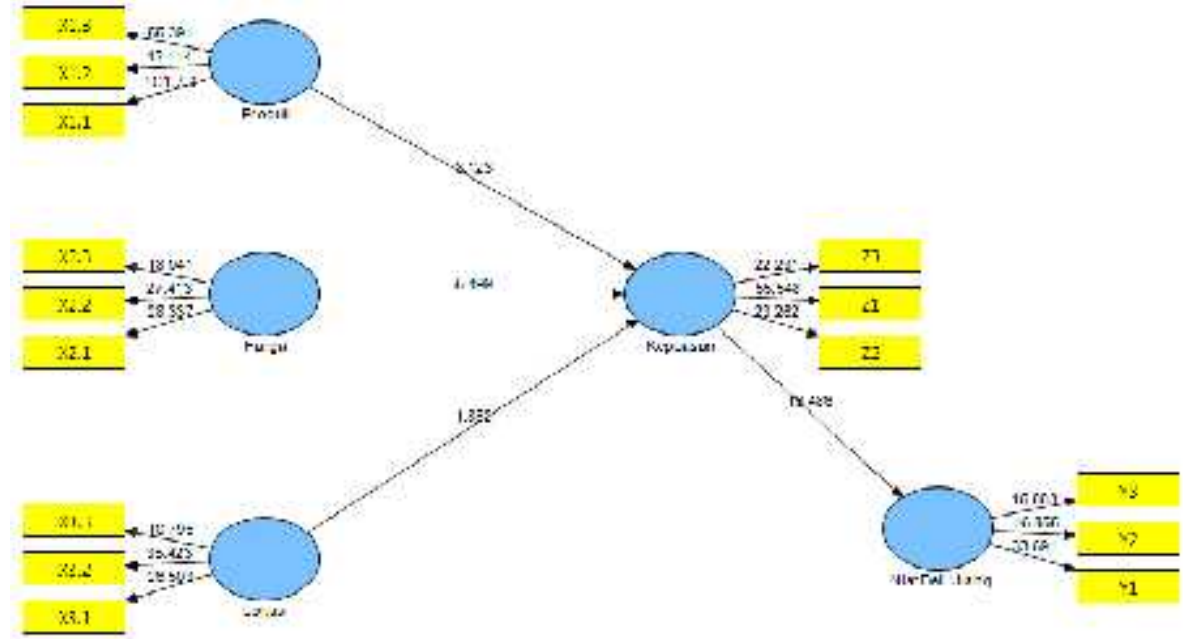

Gambar 4.3 Hasil Estimasi Bootstrapping Smart PLS 2

\section{a. $R$-Square dan $Q$-Square}

Pada penilaian goodness of fit ini adalah dengan melihat nilai $R$-square yang dihasilkan melalui estimasi Smart PLS pada setiap jalur. Berdasarkan pengolahan data dengan metode PLS diperoleh $R$-square sebagai berikut. 
Tabel 4.14

Nilai $R$-square

\begin{tabular}{|l|c|}
\hline \multicolumn{1}{|c|}{ Variabel } & $R$ Square \\
\hline Kepuasan Konsumen & 0,547 \\
\hline Niat Pembelian Ulang & 0,441 \\
\hline
\end{tabular}

Pada jalur hubungan antara variabel produk, harga dan lokasi terhadap kepuasan konsumen diperoleh nilai $R$-square sebesar 0,547 yang berarti bahwa persentase keragaman dari penilaian responden atas kepuasan yang dirasakan dapat dijelaskan oleh variabel produk, harga dan lokasi sebesar 54,7\%. Sementara itu, untuk sisanya sebesar 45,3\% dijelaskan oleh variabel lain diluar model penelitian.

Sedangkan pada jalur hubungan antara kepuasan konsumen terhadap niat pembelian ulang diperoleh $R$-square sebesar 0,441 yang berarti bahwa persentase keragaman atas persepsi niat pembelian ulang nasabah dapat dijelaskan oleh variabel kepuasan konsumen sebesar 44,1 $\%$ sedangkan untuk sisanya sebesar 55,9\% dijelaskan oleh variabel lain diluar model penelitian.

Untuk nilai $\mathrm{Q}^{2}$ dihitung dengan formula $\mathrm{Q}^{2}=1-\left(\mathrm{P}_{\mathrm{e} 1}^{2} \times \mathrm{P}_{\mathrm{e} 2}^{2}\right)$ dengan $\mathrm{Q}^{2}$ merupakan koefisien determinasi total, $\mathrm{P}^{2}$ ei adalah parameter error setiap persamaan yang dihitung dengan formula $\mathrm{P}_{\mathrm{ei}}=\sqrt{1-R i^{2}}=\left(1-\mathrm{Ri}^{2}\right)^{0.5}$. Berdasarkan hasil analisis diperoleh $\mathrm{R}_{1}{ }^{2}=0,514$ dan nilai $\mathrm{R}_{2}{ }^{2}=0,441$ sehingga diperoleh nilai $\mathrm{P}_{\mathrm{e} 1}$ dan $\mathrm{P}_{\mathrm{e} 2}$ sebagai berikut:

$\mathrm{P}_{\mathrm{e} 1}^{2}=(1-0,514)^{0.5}=0,453$

$\mathrm{P}_{\mathrm{e} 2}{ }^{2}=(1-0,441)^{0.5}=0,559$

Didapat nilai koefisien determinasi total sebagai berikut:

$\mathrm{Q}^{2}=1-\left(\mathrm{P}_{\mathrm{e} 1}^{2} \times \mathrm{P}_{\mathrm{e} 2}^{2}\right)$

$\mathrm{Q}^{2}=1-(0,453 \times 0,559)$

$\mathrm{Q}^{2}=1-0,253=0,747$

Berdasarkan hasil perhitungan diperoleh nilai predictive relevance sebesar 0,747 yang berarti bahwa keragaman dari semua data penelitian pelayanan Gadai Emas IB Barokah Bank Jatim Cabang Syariah dapat dijelaskan oleh model struktural yang dibentuk sebesar 74,7\% sedangkan sisanya sebesar 25,3\% dijelaskan oleh variabel lain yang tidak digunakan dalam model.

\section{b. Inner Weight}

Evaluasi inner weight dipergunakan untuk melakukan pengujian atas hipotesis penelitian yang telah dirumuskan. Hasil dari pengujian hipotesis penelitian berdasarkan evaluasi inner weight adalah sebagai berikut:

Tabel 4.15

Pengaruh Langsung (Direct Effect)

\begin{tabular}{|l|c|c|c|}
\hline \multicolumn{1}{|c|}{ Direct Effect } & $\begin{array}{c}\text { Original } \\
\text { Sample }\end{array}$ & T-statistic & Keterangan \\
\hline $\begin{array}{l}\text { Produk } \rightarrow \text { Kepuasan } \\
\text { Konsumen }\end{array}$ & 0,288 & 3,123 & Signifikan \\
\hline $\begin{array}{l}\text { Harga } \rightarrow \text { Kepuasan } \\
\text { Konsumen }\end{array}$ & 0,428 & 5,499 & Signifikan \\
\hline $\begin{array}{l}\text { Lokasi } \rightarrow \text { Kepuasan } \\
\text { Konsumen }\end{array}$ & 0,143 & 1,882 & $\begin{array}{c}\text { Tidak } \\
\text { Signifikan }\end{array}$ \\
\hline $\begin{array}{l}\text { Kepuasan Konsumen } \rightarrow \text { Niat } \\
\text { Pembelian Ulang }\end{array}$ & 0,664 & 13,486 & Signifikan \\
\hline
\end{tabular}




\section{Hipotesis I}

Hasil estimasi jalur pengaruh antara produk terhadap kepuasan konsumen adalah 0,288 dengan nilai $T$-statistics 3,123. Berdasarkan hasil diketahui bahwa nilai $T$-statistics 3,123>1,96, maka dapat disimpulkan bahwa variabel produk berpengaruh signifikan terhadap kepuasan konsumen. Pengaruh yang terjadi pada jalur bersifat positif yang berarti apabila penilaian atas produk semakin baik maka kepuasan konsumen juga akan semakin tinggi. Mengacu pada hasil pengujian hipotesis $\mathrm{H}_{1}$ terbukti kebenarannya.

\section{Hipotesis II}

Hasil estimasi jalur pengaruh antara harga terhadap kepuasan konsumen adalah 0,428 dengan nilai $T$-statistics 5,499. Berdasarkan hasil diketahui bahwa nilai $T$-statistics 5,499 > 1,96, maka dapat disimpulkan bahwa variabel harga berpengaruh signifikan terhadap kepuasan konsumen. Pengaruh yang terjadi pada jalur bersifat positif yang berarti apabila penilaian atas harga semakin baik maka kepuasan konsumen juga akan semakin tinggi. Mengacu pada hasil pengujian hipotesis $\mathrm{H}_{2}$ terbukti kebenarannya.

\section{Hipotesis III}

Hasil estimasi jalur pengaruh antara lokasi terhadap kepuasan konsumen adalah 0,143 dengan nilai $T$-statistics 1,882 . Berdasarkan hasil diketahui bahwa nilai $T$-statistics $1,882<1,96$, maka dapat disimpulkan bahwa variabel lokasi tidak berpengaruh signifikan terhadap kepuasan konsumen. Pengaruh yang terjadi pada jalur bersifat positif yang berarti apabila penilaian atas lokasi semakin baik maka kepuasan konsumen juga akan semakin tinggi. Mengacu pada hasil pengujian hipotesis $\mathrm{H}_{3}$ terbukti kebenarannya.

\section{Hipotesis IV}

Hasil estimasi jalur pengaruh antara kepuasan konsumen terhadap niat pembelian ulang adalah 0,664 dengan nilai T-statistics 13,486. Berdasarkan hasil diketahui bahwa nilai T-statistics 13,486 > 1,96, maka dapat disimpulkan bahwa variabel kepuasan konsumen berpengaruh signifikan terhadap niat pembelian ulang. Pengaruh yang terjadi pada jalur bersifat positif yang berarti apabila penilaian atas kepuasan semakin baik maka niat pembelian ulang juga akan semakin tinggi. Mengacu pada hasil pengujian hipotesis $\mathrm{H}_{4}$ terbukti kebenarannya.

\section{SIMPULAN \& SARAN}

\section{Simpulan}

Berdasarkan rumusan masalah yang telah dianjukan, hipotesis, hasil analisis, dan pembahasan yang telah ada, maka diperoleh kesimpulan dalam penelitian ini yaitu sebagai berikut:

1. Produk berpengaruh positif dan signifikan terhadap kepuasan nasabah pada Gadai Emas IB Barokah Bank Jatim Cabang Syariah Surabaya.

2. Harga berpengaruh positif dan signifikan terhadap kepuasan nasabah pada Gadai Emas IB Barokah Bank Jatim Cabang Syariah Surabaya.

\section{Saran}

1. Lokasi tidak berpengaruh signifikan terhadap kepuasan nasabah pada Gadai Emas IB Barokah Bank Jatim Cabang Syariah Surabaya.

2. Kepuasan Konsumen berpengaruh positif dan signifikan terhadap niat pembelian ulang nasabah pada Gadai Emas IB Barokah Bank Jatim Cabang Syariah Surabaya. 


\section{DAFTAR PUSTAKA}

Agyapong, K. (2016). The Effect of Marketing Strategy on Consumer Satisfaction: Distance Education Perspective. International Journal of Innovative and Research Development, 6(7), 133-139. https://doi.org/: 10.24940/ijird/2017/v6/i7/JUL17020

Alma, B. (2014). Manajemen Pemasaran dan Pemasaran Jasa. Bandung: CV Alfabeta.

Ehsani, Z., \& Ehsani, M. (2015). Effect of Quality and Price on Customer Satisfaction and Commitment in Iran Auto Industry. International Journal of Service Science, Management and Engineering, 1(5), 52-56.

Kana, T. (2018). The Effect of Location and Facilities Services User Satisfaction Container Loading and Unloading in Port of Indonesia IV (Persero) Branch Merauke. International Journal of Social Science and Business, 2(1), 21-27. https://doi.org/10.23887/ijssb.v2i1.11900

Kotler, P., \& Armstrong, G. (2016). Principles of Marketing (16th ed.). New Jersey: Pearson Prentoice Hal.

Kotler, P., \& Keller, K. L. (2016). Marketing Management, Global Edition. New York: Pearson Education Limited.

Lovelock, C., \& Wright, L. K. (2005). , 2011, Managemen Pemasaran Jasa(Terjemahan), PT Indeks (GRAMEDIA GROUP) Jakarta. Jakarta: Indeks.

Lupiyoadi, R., \& Hamdani, A. (2014). Pemasaran Jasa. Jakarta: Salemba Empat.

Palmer, A., \& Keown-McMullan, C. (2000). Equity and repurchase intention following service failure. Journal of Services Marketing, 14(6), 513-528. https://doi.org/10.1108/08876040010347624

Razak, I., Nirwanto, N., \& Triatmanto, B. (2016). The Impact of Product Quality and Price on Customer Satisfaction with the Mediator of Customer Value. Journal of Marketing and Consumer Research, 30, 59-68.

Tjiptono, F. (2015). Strategi Pemasaran Edisi 4. Yogyakarta: Andi.

Tjiptono, F., \& Diana, A. (2015). Palanggan Puas? Tak Cukup! Yogyakarta: Andi.

Varga, A., Dlačić, J., \& Vujičić, M. (2014). Repurchase intentions in a retail store - exploring the impact of colours. Ekonomski Vjesnik, 27(2), 229-244.

Zeithaml, V. A., \& Bitner, B. (2000). Service Marketing: Integrating Customer Focus (2nd ed.). New York: McGraw-Hill Inc.

Zeithaml, V. A., Bitner, M. J., \& Gremler, D. D. (2006). Services marketing: integrating customer focus across the firm (4th ed.). Boston, MA: McGraw-Hill/Irwin. 